\title{
Different routes, common directions? Activation policies for young people in Denmark and the UK
}

Lindsay C, Mailand M. Different routes, common directions? Activation policies for young people in Denmark and the UK

Int J Soc Welfare 2004: 13: 195-207 (C) Blackwell Publishing, 2004.

This article analyses and compares the development of activation policies for young people in Denmark and the UK from the mid-1990s. Despite their diverse welfare traditions and important differences in the organisation and delivery of benefits and services for the unemployed, both countries have recently introduced large-scale compulsory activation programmes for young people. These programmes share a number of common features, especially a combination of strong compulsion and an apparently contradictory emphasis on client-centred training and support for participants. The suggested transition from the 'Keynesian welfare state' to the 'Schumpeterian workfare regime' is used as a framework to discuss the two countries' recent moves towards activation. It is argued that while this framework is useful in explaining the general shift towards active labour-market policies in Europe, it alone cannot account for the particular convergence of the Danish and British policies in the specific area of youth activation. Rather, a number of specific political factors explaining the development of policies in the mid-1990s are suggested. The article concludes that concerns about mass youth unemployment, the influence of the 'dependency culture' debate in various forms, cross-national policy diffusion and, crucially, the progressive re-engineering of compulsory activation by strong centre-left governments have all contributed to the emergence of policies that mix compulsion and a commitment to the centrality of work with a 'client-centred approach' that seeks to balance more effective job seeking with human resource development. However, attempts to combine the apparently contradictory concepts of 'client-centredness' and compulsion are likely to prove politically fragile, and both countries risk lurching towards an increasingly workfarist approach.

\author{
Colin Lindsay1, Mikkel Mailand2 \\ 1 Employment Research Institute, Napier University, UK \\ 2 Employment Relations Research Centre, University of \\ Copenhagen, Denmark
}

Key words: Denmark, UK, unemployment, activation, youth

Colin Lindsay, Research Associate, Employment Research Institute, Napier University, Edinburgh EH14 1DG, UK

E-mail: c.lindsay@napier.ac.uk

and/or

Dr Mikkel Mailand, Assistant Research Professor, Employment Relations Research Centre, University of Copenhagen, Linnesgade 22, DK 1361 Copenhagen K, Denmark

E-mail: mm@faos.dk

Accepted for publication August 27, 2003

\section{Introduction}

The 1980s and 1990s saw welfare states across the EU come under increasing pressure as the tenacity of the European unemployment problem raised fiscal and political challenges to existing social policy structures (Finn, 2000; Nordlund, 2000). A common response amongst many EU states has been to adopt active labour-market policies (ALMPs) in an attempt to assist the unemployed into work and so curtail expenditure on 'passive' social security benefits (Evans, 2001). These 'activation' measures have often targeted young people, as policy makers have recognised the particular barriers to work faced by those seeking to take their first steps in the labour market. 1

The aim of this article is to trace the development of activation programmes for unemployed young people in two EU states, Denmark and the UK, during the 1990s, and to examine the economic, social and political forces that have driven the policy reform agenda in these

\footnotetext{
1 Activation is here defined as any policy seeking to integrate unemployed people into the labour market by requiring some form of compulsory job search, training or work-based activity.
} 
countries. Despite their distinctive welfare traditions, both countries developed similar large-scale activation programmes during the 1990s, which combine compulsory work-focused activity with holistic, client-centred training and counselling services. This article seeks to establish the extent to which this apparent process of policy convergence marks a real and lasting shift in the approach of either (or both) countries, and explain the similarities and continuing differences in their activation strategies. It should be noted that our remarks are limited mainly to the development and content of policy programmes, and have less to do with impact and implementation.

Following this introduction, the second part of the article examines the recent development of youth activation policies in the two countries. Next, common and distinctive features of the Danish and British policies are discussed. The following two sections then discuss potential explanations for the two countries' increasingly similar policies for dealing with unemployed young people, focusing first on theories about the transition from the 'Keynesian welfare state' to the 'Schumpeterian workfare regime', and then highlighting a number of specific economic and political factors that coincided to influence policy development in Denmark and the UK. Lastly, we conclude that welfare-regime oriented discussions of recent shifts in activation policies for young people need to be supplemented by policy-specific analyses that can identify and explain changes at odds with expected patterns of development.

\section{The evolution of activation policies for young people in Denmark and the UK}

\section{Denmark: the development of active labour-market policies before 1993}

The development of Danish ALMPs initially reflected an attempt to respond to the country's prolonged unemployment crisis of the 1970s and 1980s. As policy makers began to realise that the crisis was a far from temporary phenomenon, steps were taken to restrict the coverage and level of unemployment protection, and a limited range of active measures, mainly targeting young people, was introduced. However, the Social Democratic government's employment subsidy (Jobtilbudsordningen) and work experience projects (Ung $i$ Arbejde and later Jobskabelsesordningen) made little impact on private employers, with the result that local authorities soon became the primary employer of activation participants.

The centre-right coalition that came into power in 1982 was less convinced of the value of the ALMP approach and introduced budget cuts, combined with a series of reductions in unemployment benefit levels (Etherington, 1998). Within those active measures that were retained, education and training was emphasised over more costly employment subsidy options, for instance through the introduction of the "educational offer scheme' (Uddannelsestilbudsordningen). Nevertheless, the persistence of the unemployment problem forced activation back on to the political agenda in the late 1980s. Changes in the national and international policy discourse had made it more acceptable to discuss whether the behaviour of the unemployed could be altered by economic incentives and compulsory activation measures. Denmark's first compulsory activation programme, the Youth Allowance Scheme, directed towards social assistance claimants aged 18-19, was introduced in 1990 (Rosdahl \& Weise, 2000). However, progress in terms of specific policy developments was slow prior to the election of a Social Democratic-led government in 1993, as ALMP development in Denmark continued to lag behind its Scandinavian neighbours (Hvinden, Heikkila \& Kankare, 2001; Johansson, 2001).

\section{Denmark: reforms to activation policies 1993-2000}

A new centre-left government was formed soon after the publication of the report of the tripartite pre-legislative Zeuthen Committee (Zeuthen-udvalget) in 1992. Offering advice echoed by the OECD (OECD, 1993), the report called for a major shift towards activation policies in an attempt to counteract structural unemployment and curtail the seemingly inexorable rise of spending on 'passive' social security measures. The report's findings were largely accepted by the Social Democratic coalition, and formed the basis for a radical series of policy reforms introduced from 1993. The existing tripartite bodies were reformed, and under their leadership provision for the insured unemployed is now delivered through the public employment service (AF), either unilaterally or through local partnerships between the agency and other actors such as local authorities, training providers and employers, or via subcontracting arrangements. Since 1998, a similar institutional framework has been used to deliver policies for uninsured social assistance claimants, but with local authorities rather than the $\mathrm{AF}$ as the main responsible actor, assisted by broader multipartite bodies. The system for social assistance clients is rather more decentralised because of the semi-autonomous role granted to local authorities, compared with the role of the regional employment services, which remain under close ministerial control (Etherington, 1997).

These new frameworks oversee the delivery of a range of employment and training measures (Mailand, 1999; Rosdahl \& Weise, 2000), including:

- Individual guidance: involving the agreement of individual action plans for each unemployed person as a precondition for the following measures. 
- Education and training: delivered through vocational training or traditional further education institutions, and by far the most used measure for the insured unemployed.

- Job training: mostly used for insured clients and involving subsidised work placements for at least six months with a public or (far less likely) private employer.

- 'Individual' job training: designed to improve the basic personal skills, motivation and job-readiness of participants, and targeted at more disadvantaged clients, mostly those claiming social assistance. Most often delivered through 'employment projects' run by local authorities. ${ }^{2}$

- Jobs on special terms and conditions: flexible workplacement initiatives targeted at (uninsured) unemployed people with a reduced capacity to work.

The establishment of these options has been linked to a more aggressive approach to activation, which has particularly impacted on the young. In 1996, the existing Youth Allowance Scheme for uninsured young people was supplemented by the Special Youth Initiatives, targeted at the insured unemployed aged under 25 with no formal educational or vocational qualifications. Persons meeting the eligibility requirements have a right and duty to participate in education or training for at least 18 months, and receive a training allowance equivalent to about 50 per cent of unemployment benefits. It has been suggested that this benefit reduction has 'encouraged' many young people to enter full-time education or work rather than risk becoming subject to Special Youth Initiatives (NordLarsen, 1997). Young people with qualifications face a similar level of compulsion, so that they are dutybound to accept activation before they reach a sixmonth duration threshold. Further changes have tightened eligibility criteria and entitlement periods for unemployment (insurance) benefits, while activation is now imposed on all older job seekers before they have been unemployed for twelve months.

The reform process has also targeted social assistance claimants (who are subject to 'social policy' delivered through local authorities). However, uninsured young people are required to participate in activation earlier than insured - prior to a three-month threshold. The pattern of programme usage also differs between the two client groups (see above). The Danish reforms can be viewed as having sought to balance compulsion with choice and individually tailored services. There remains, however, some doubt about the extent to which activation offers a genuine choice for participants and about the

2 Further reforms in 2003 saw these programmes replaced by 'practical training and workplace introduction' measures, aimed at those not yet ready for work-based training. quality of the meas-ures, especially those directed towards the uninsured (Abrahamson, 1999).

\section{The UK: the Conservatives and labour market policy} (1979-1997)

The origins of the UK's current affection for aggressively supply-side activation policies can, to some extent, be traced to the Conservatives' response to the country's unemployment crisis of the 1980s. Throughout the early 1980s, the Conservative government established a range of new training programmes targeted at young people and the long-term unemployed. Yet, prior to 1986, the stricter regulation of unemployment benefit claimants was not seen as a particularly important element in labour-market policy. Indeed, between 1982 and 1986 unemployed people were not even required to attend public employment service (ES) job centres to 'sign on' as actively seeking work. The result was a system that failed to engage with job seekers - a system more recently characterised by government officials as 'essentially passive, with no responsibilities to counterbalance the rights of benefits receipt' (Wells, 2001: 8).

However, as unemployment declined in the late 1980s and the influence of the 'underclass' debate spread amongst policy makers, the Conservative government turned to more punitive and restrictive measures. The objective was simple: to activate the long-term unemployed by making life on benefit as unattractive as possible, thus encouraging job seekers to take the most direct route possible into work. A number of changes to the regulation of benefits after 1986 imposed a far stronger degree of compulsion on the behaviour of all job seekers, and particularly young people and the long-term unemployed. The so-called 'stricter benefit regime' that emerged over the next decade rendered participation in a range of activities compulsory in all but name (Deacon, 1998).

It is something of an overstatement to suggest that the Conservatives established a fully functioning workfare system in the UK (Dolowitz, 1997), but the increased compulsion and conditionality introduced between 1986 and 1997 did produce a more authoritarian way of dealing with job seekers. The last decade of Conservative government also saw a significant withdrawal of support from the work-based training policies that had been promoted during the early to mid-1980s (Finn, 2000). Those programmes that were still provided increasingly focused on job search and motivation, and were therefore considerably less expensive to operate than work-based training schemes. Only in the area of policies for unemployed school leavers (aged 16-17) did the government retain training (rather than placement into work) as their primary objective. It is also in this area that the British system has come closest to imposing workfare-style compulsory activity. The 1988 
Social Security Act withdrew the automatic entitlement to benefit from most 16-17-year-olds, who were instead granted a 'right to training'. The withdrawal of benefits from those refusing to take up training has led some to suggest that the 1988 act amounted to the introduction of 'training-fare' in the UK (ILO, 1998).

\section{UK activation policies since 1997: a New Deal for (some) young people}

The election of a new Labour government in May 1997 marked a significant change in the direction of British activation policies for some young people. For 16-17-year-olds, however, the 'training-fare' system inherited from the Conservative government has remained largely intact. The introduction of the New Deal is clearly the most important recent development in British activation policies for other young people. Introduced in 1998, the New Deal for Young People is the government's main active labour-market policy, directed towards those aged 18-24 who have been registered as unemployed for more than six months. It is compulsory, and those who refuse to participate face losing benefits for two to four weeks on a recurring basis, and eventually a suspension of up to 26 weeks. The New Deal features a number of training and support elements designed to improve the basic skills and employability of participants, namely:

- 'Gateway' assistance for up to four months: participants receive a mix of counselling, job-search training and careers advice. They are assigned a personal adviser to ensure continuity of service and provide one-to-one counselling. The aim of the Gateway is to assist the most 'job-ready' clients to locate employment immediately, and to prepare those who require further assistance for a choice of four training options.

- The four options: full-time, subsidised employment for up to six months, with participants paid at the 'rate for the job' and given training towards a qualification; full-time education and training for those without formal qualifications; work experience within the voluntary sector; or participation on Environmental Task Force projects, each for up to six months. (An additional 'self-employment' option has now been added, offering support towards starting and running a business.) Whereas participants on the New Deal's employment option are paid at the rate for the job, other trainees receive only their benefits, plus a small expenses allowance (DfEE, 1998).

The New Deal's performance in terms of achieving job entry for participants has been impressive (Riley \& Young, 2001). The choice of training options and the client-centred, case management approach of the New Deal distinguish it from its predecessors in the field, and have proved popular with many participants (Millar, 2000). However, considerable concerns remain, linked to the low proportion of participants entering the (supposedly crucial) subsidised employment option and the quality of provision delivered through alternative training options (Hasluck, 2000). The programme's strong emphasis on attaining job entry targets also threatens to undermine its commitment to providing training and personal development opportunities for often-vulnerable clients.

\section{A common approach to activation for young people?}

The above discussion highlights the broadly similar approach adopted by Danish and British activation policies for young people in a number of areas - in their attempts to re-balance the relationship between rights and responsibilities, adoption of a client-centred approach to dealing with activation participants, prioritisation of 'real work' experience and development of local, partnership-based delivery mechanisms.

- A re-balancing of rights and obligations: the recent reforms in both countries have forcefully restated the link between the rights and responsibilities of benefit claimants. The post-1993 reforms in Denmark have emphasised the 'duty' of the unemployed to participate. Whilst the UK has a longer-standing tradition of strong compulsion, the New Deal represents the first major compulsory work-focused programme for unemployed 'adults'. Both countries use benefit sanctions to impose strong compulsory measures.

- A client-centred approach: both countries' major activation programmes offer participants a choice of provision and seek to tailor services to fit the individual's needs. The New Deal allocates clients a personal advisor, whilst 'needs-oriented' individual action plans are central to the Danish approach (Larsen \& Stamhus, 2000). Clients appear to have both noticed and valued these features (Hasluck, 2001; Olesen, 2001)

- A real work focus: recent activation policies in both countries have prioritised providing opportunities for clients to gain experience within a 'real work' environment. These opportunities have been created through the provision of substantial wage subsidies to employers. It should, however, be noted that in practice both countries' new programmes have come to rely on other training options (such as the longstanding Work-Based Training for Adults in the UK and 'individual job training' and 'education and training' in Denmark).

- Delivery through local partnerships: in both countries, new local partnership bodies have played an important role in planning and delivering activation policies. As noted below, Denmark's tripartite and multipartite bodies reflect that country's strong social partnership traditions, while the membership of New Deal partnerships reflect the private-sector orientation that has 
long dominated training policies in the UK. Nevertheless, both countries have similarly sought to establish new ways of delivering activation, with public authorities at the centre of local partnerships designed to provide a broad range of service delivery expertise.

There of course remain important structural differences distinguishing the two countries' systems of delivering youth activation policies. Perhaps most importantly, Denmark distinguishes between the insured and the uninsured unemployed. The unemployment insurance and social assistance systems operate separately, and activation policies (although similar in their aims) are administered through different local agencies and governed by different regulations. This contrasts with a UK system in which social assistance and unemployment insurance clients claim a single benefit - the Jobseeker's Allowance (JSA) - and are subject to the same benefit regulations. Although the vast majority of New Deal participants are income-based social assistance claimants, this reflects the manner in which the programme's duration threshold coincides with the severely restricted eligibility period for contributions-based benefits (six months).

The context within which unemployment and welfare policies have developed and are delivered also differs markedly in the two countries. In terms of spending on the specific area of youth activation, the two countries converged during the late 1990s, with expenditure in the UK standing at 0.06 per cent of GDP in 1997-98, compared to 0.08 per cent in Denmark (1998 figures). However, expenditure on youth activation measures has since fallen to 0.04 per cent of GDP in the UK in 1999-2000, while slightly increasing in Denmark to 0.10 per cent of GDP in 2000. Furthermore, total spending on activation policies is far higher in Denmark, at 1.56 per cent of GDP compared with only 0.36 per cent in the UK (OECD, 2002).

These differences reflect the expansion of comprehensive activation measures to other client groups in Denmark, while the main focus of British policy remains firmly on the young and long-term unemployed (groups which have seen substantial falls in claimant numbers in recent years). It has also been suggested that low levels of spending per client in the UK are an inevitable consequence of the current system's commercially driven approach to delivering training (for example Jones, 1997). It is certainly clear that the UK approach continues, to some extent, to emphasise shorter, less-expensive training interventions, with training providers rewarded on the basis of job entry rates.

The two countries' benefits systems in themselves represent another important challenge to any more general idea of a common Danish-British approach. OECD data suggests that gross unemployment benefit replacement rates in the mid-1990s were approximately 71 per cent in Denmark compared with only 18 per cent in the UK, well below the OECD average of 31 per cent
(Martin, 1996). Attempts to arrive at estimates for average net replacement rates (accounting for housing benefits available to the unemployed and taxes levied on those in work) place the UK much nearer Denmark, at 62 per cent compared with 70 per cent (Standing, 2000). Nevertheless, there remains a gulf in the disposable income available to unemployed people in the two countries, which is reflected in the far higher proportion of unemployed Britons living in low-income households (Salomaki \& Munzi, 1999).

There are practical implications for activation policies and their subjects. Denmark's higher net incomes and more generous replacement rates have meant that training programmes offering the participants only benefits - or benefits plus a small training allowance - have been introduced with little controversy. In the UK, meanwhile, 'benefit plus' training options within the New Deal have been viewed as the bottom layer of a 'hierarchy of options', and are far less valued than training delivered through subsidised employment, paying participants at the 'rate for the job' (Peck, 1999). A similar hierarchy of options exists in Denmark, but the relatively high replacement rates make the variation in the financial gains between the different options less profound.

Measures of benefit regulation similarly highlight differences in the two countries' approaches. A survey of selected OECD states concluded that the UK and (post-1993) Denmark maintain a similar degree of strictness in their 'availability for work' regulations (Danish Ministry of Finance, 1998). However, while the relevant national agreements govern the wage levels at which Danish job seekers are required to target their search activities, unemployed people in the UK are, at least in theory, required to demonstrate full wage flexibility (Clasen, Kvist \& van Oorschot, 2001). Otherwise, levels of compulsion at first appear more severe in Denmark, with those refusing a 'reasonable offer' potentially subject to a permanent suspension of unemployment benefits. As the OECD (2000: 135) has noted:

In ... the United Kingdom, repeated refusals of an ALMP placement attract a relatively light sanction. But in Denmark, although a first refusal of a suitable job leads only to a one week sanction, a first refusal of an ALMP placement within the so-called 'active period of benefit' . . . leads to exclusion with no re-admittance until 52 weeks of work have been performed. ${ }^{3}$

\footnotetext{
3 According to legislation introduced in 2003, at the first refusal to accept a reasonable offer, insured clients lose their right to unemployment benefits for three weeks, while uninsured clients have their social benefits cut by a third for the same period. A second refusal leads to the same benefit reduction until 300 hours of unsubsidised employment within ten weeks have been completed, but for the uninsured clients the sanction period cannot exceed 20 weeks. If insured unemployed people are paid social assistance during the sanction period, these payments must be refunded.
} 
In the UK, while pressure tends to be applied gradually on those refusing measures under the New Deal, the final sanction of a long-term suspension of benefits leaves young people (virtually all of whom are already receiving means-tested social assistance) with recourse only to 'hardship' payments, distributed at the discretion of ES officers. ${ }^{4}$ There is no hardship fund for social assistance clients facing benefits sanctions in Denmark, and some municipalities have faced criticism after suspending all social benefits received by some 'unwilling' uninsured clients (Schultz, 2001). However, the number of sanctions applied to social assistance claimants is low, and it has been suggested that many uninsured people facing severe barriers to work are de facto 'protected' from activation by civil servants within the municipalities (Larsen, Abildgaard, Bredgaard \& Dalsgaard, 2001). In broader terms, despite Denmark's apparently stricter application of activation measures, unemployment benefit sanctions generally appear to be applied much more regularly in the UK (in 10.3 per cent of cases, compared with 4.3 per cent in Denmark) (Grubb, 1999).

Lastly, returning to administrative arrangements, Denmark's social partnership mechanisms are not replicated in the UK. The strength of the Danish trade unions and employers' organisations is reflected in the role of tripartite bodies in developing and delivering ALMPs, although at regional and local level, trade unions appear to be rather more influential than employers' representatives (Mailand, 1999). 'Social policy', directed towards the uninsured unemployed, has witnessed less social partnership because of the dominant role of local authorities (Etherington, 1997), but here the recent establishment of new multipartite bodies at local and national level to offer 'guidance' on delivering activation measures may result in further progress (Mailand \& Andersen, 2001).

In the UK, the trade union movement has traditionally played little or no role in labour-market policy development. Indeed, the country has only recently begun to rebuild partnership relations after its few meaningful tripartite institutions were dismantled during the 1980s. Training and Enterprise Councils, which were established by the Conservatives in 1988 and until recently planned and delivered local training in most of the UK, were profit-making organisations drawing the majority of their members from the business community (but their core funding from central government). Although their successor Learning and Skills Councils (LSC) now seek

4 Hardship payments are available to persons in pre-defined vulnerable groups and those who can 'convince' an ES hardship officer that they or their immediate family will face financial hardship without assistance. Hardship payments are paid at 60 per cent or 80 per cent of the value of incomebased JSA, depending on circumstances. to balance private-sector and other interests within their membership (and guarantee trade union representation on their boards), they remain business-oriented in their approach. Trade unions, the business community and other interested parties have also been included in the national-level New Deal Taskforce - which has planned the policy's development - and in partnerships coordinating delivery at the local level. It remains to be seen whether the apparently more inclusive New Deal and LSC partnerships will pave the way for a new era of multipartite cooperation in the UK. That these partnerships have been established at all represents a considerable step forward.

As noted above, employers' organisations play a role in the partnerships overseeing policy development in both countries. However, the private sector also plays an important role in the delivery of programmes in the UK. Private-sector agencies provide some New Deal training elements in most parts of the country, and in 12 of the New Deal's 144 local delivery areas private companies have been selected to lead the development and delivery of the programme. In Denmark, the private sector plays a more limited role in the delivery of education and training, but a larger share of the private companies take part in subsidised employment programmes than in the UK (Martin, forthcoming).

In conclusion, the British and Danish systems remain distinguished by a number of general features within their unemployment protection systems. Nevertheless, in the specific policy area of activation for young people, the two countries have converged in recent years. Both Denmark and the UK have introduced policies that combine strong compulsion and work-focused training, reflecting an attempt to restate the centrality of work as an activity for young adults. Yet activation policies for young people in Denmark and the UK also clearly reflect what might be termed a client-centred approach, in their commitment to dealing with young people as individuals and offering a choice of provision. Lodemel (2000) has defined the same common theme as a 'human resource development (HRD)-oriented approach' - one that focuses on providing the unemployed with more in terms of choice, opportunities and the development of human resources - in contrast with a 'labour market attachment (LMA) approach', which offers less choice and personal development and instead emphasises control, coercion and economic incentives to encourage job entry.

\section{Explaining the development of activation policies for young people in Denmark and the UK in the 1990s}

\section{Activation in Denmark and the UK: beyond welfare regime theory}

In seeking to explain the development of Denmark's active labour market policies, Torfing (1999) has provided a 
useful model based on the ongoing transition from the 'Keynesian welfare state' to the 'Schumpeterian workfare regime'. Torfing, following Jessop (1994), argues that this international shift in policy orientation is rooted in the crisis of Fordism (experienced by developed countries most vividly as the fiscal crisis of the welfare state and seemingly permanently high unemployment). The ideal-type Schumpeterian workfare regime that has emerged in response to this crisis shares the objectives of traditional Keynesian models of welfare - to secure the conditions for both capital accumulation and social reproduction. However, its methods are different: it emphasises increased activation and innovation (through policy interventions on the supply-side); it prioritises measures to promote economic competitiveness; and it 'subordinates social policy to the requirements of labour market flexibility'.

Importantly, Torfing argues that Denmark's transition to workfarism has been tempered by the efforts of successive governments to 'detach workfare from its neo-liberal origin'. The emerging Danish workfare state is therefore 'offensive' rather than 'defensive' in its approach. That is, the Danish strategy prioritises activation rather than benefit reductions, human resource development rather than mere job-search efficiency, training rather than work for benefit and empowerment rather than control. But what of the UK? It is suggested that, like other 'Anglo-Saxon' states, the UK has adopted a defensive and typically neo-liberal approach. Echoing critics of the benefit-cutting and market-oriented policies of the Conservative era (Jessop, 1995; Peck \& Jones, 1995), Torfing cites the JSA reform and the establishment of employer-dominated Training and Enterprise Councils as paradigmatic examples of such a neo-liberal strategy.

Torfing's description of Denmark's offensive, neostatist strategy (which perhaps understates the regulation and compulsion actually experienced by Danish job seekers) shares similarities with the 'HRD-oriented approach' identified by Lodemel, and the 'client-centred approach' discussed above. Yet our analysis and Lodemel's broad categorisation characterise Denmark and the UK as pursuing broadly similar paths, whereas Torfing seeks to portray the British approach as more typical of its own long-standing liberal welfare arrangements. Torfing hints that the application of neo-statist and neoliberal ideal types may be over-simplistic by noting that Anglo-Saxon states such as the UK have 'until recently' adopted more defensive strategies (and acknowledging strong neo-corporatist features in the Danish approach).

Nevertheless, this raises a more general point. For Torfing, the differences between Danish activation and American-style workfare (and the similar British 'stricter benefit regime') can be traced to the institutional and political features of the 'social-democratic' and 'liberal' welfare regimes from which these national-level policies have emerged (see for example Esping-Andersen, 1990). It would appear that these traditional theoretical models, predicated on the distinguishing features of countries such as Denmark and the UK, are of greater value in offering general insights about the common forces moulding broadly similar welfare states, than explaining the more recent convergence of otherwise dissimilar systems around a shared approach in specific policy areas, such as youth activation.

How then can we best explain the partial but significant convergence of Danish and British activation policies for young people? We now turn to a number of specific political factors which may help to explain the broadly similar approach adopted by the two countries, namely: policy responses to mass unemployment and the changes of government that have shaped recent reforms; the changing international policy discourse; and cross-national policy diffusion. Lastly, we discuss the impact of these factors in relation to the context provided by the two countries' welfare traditions.

\section{Political responses to mass unemployment}

In Denmark and the UK, as elsewhere, changes towards a more active labour-market policy followed periods of high unemployment, which provoked concerns regarding the social impact of long-term labour-market exclusion (particularly for young people) and the financial consequences of spiralling social security expenditure. It has been argued that the particularly high unemployment rates recorded in the two countries during the 1980s and 1990s also partly explain their recent development of client-centred, 'HRD-oriented' policies, as weak labour demand precluded the adoption (or in the UK, continuation) of more direct (LMA) forms of activation. Lodemel and Trickey (2000) argue that welfare states experiencing long periods of high unemployment are more likely to be drawn towards HRDoriented activation (which seeks to provide holistic support and training opportunities within subsidised or 'intermediate' areas of the labour market) as it becomes apparent that 'work-first' approaches are unlikely to succeed in the face of stagnant labour demand. Where labour demand is less of a problem and unemployment rates are lower, there is an incentive to move towards LMA approaches, reflecting the perception that job seekers can be quickly and directly 'inserted' into readily available vacancies within the labour market.

However, the character of the emerging policies has also reflected national and party political attitudes towards the unemployment problem. It is important to note that in both countries, the recent reforms that established the client-centred activation policies discussed above followed the election of strong centre-left governments. The formation of the Social Democratic coalition in 1993 produced Denmark's first majority 
government for 20 years, and therefore provided a rare opportunity to drive through radical policy changes. The Labour Party's landslide election victory in 1997 (replicated in 2001) similarly empowered the new British government to legislate for sweeping changes to labour-market policy with considerable ease.

It has been argued that social democratic parties are generally better placed to introduce active labour-market reforms whilst avoiding opposition to what might otherwise be seen as welfare retrenchment (Ross, 2000). Electorates in both Denmark and the UK associated the welfare state more with the political left than the right, so that the opportunity to introduce radical activation policies that would gain broad-based support was more likely to present itself to social democratic parties (Clasen, 2000). Certainly, in Denmark the Conservative-Liberal coalition of 1982-93 was more successful at restricting benefit levels and eligibility than implementing largescale activation measures $-\mathrm{a}$ task that fell to their Social Democrat-led successors. In the UK, the Conservative governments of the 1980s and 1990s similarly largely favoured the stricter benefit regime over 'make work' policies, although this may have reflected an ideological reluctance to have the state become the 'employer of last resort', rather than any concerns about the political problems of legislating for workfare.

Nevertheless, it clear that the centre-right governments that preceded the reforming social democratic administrations of the 1990s to some extent 'prepared the ground' for the current focus on compulsory activity in both Denmark and the UK. As noted above, the Conservative governments in the UK (1979-97) introduced a range of policies regulating the behaviour of the unemployed and requiring compulsory activities (including training-fare for 16-17-year-olds). The language of activation and the reality of compulsion were therefore well established by the time the Labour Party came to power. In Denmark, the compulsory measures imposed by the Conservative-Liberal coalition's Youth Allowance Scheme (1990; extended 1992) were groundbreaking in requiring young people to undertake work-based activities almost immediately upon claiming social assistance benefits (Rosdahl \& Weise, 2000). In more general terms, the pro-activation stance of the Conservative-Liberal government and their establishment of the labour-market commission that produced the influential Zeuthen report had a major effect on the policy discourse.

In both countries, it would appear that centre-right governments played an enabling role in the process of development towards the client-centred, but still compulsory activation policies eventually introduced by social democrats. By 'thinking the unthinkable', conservative parties in both Denmark and the UK moved the concept of compulsory activation into the centre of the policy debate at a time when their social democrat opponents (who succeeded them in government) would have struggled to do so. With the ideas of compulsion and activation already linked at the centre of the political agenda, social democratic governments then found it much easier to quickly adapt these ideas towards a more progressive policy agenda whilst maintaining a strong element of compulsion within the programmes that emerged. The progressive re-engineering of activation policies to include a more client-centred, HRD-oriented approach was a crucial achievement of the centre-left governments elected in Denmark and the UK in the mid-1990s. The strong element of compulsion retained within these otherwise holistic policies was to prove a lasting and convenient legacy inherited by those governments from their conservative predecessors.

\section{A shift in the policy discourse}

The positions adopted by parties of the left and right thus had a direct effect on the development of active labour-market policies in Denmark and the UK. However, these parties were responding not only to the social and fiscal pressures created by high unemployment, but also to broader shifts within the international policy discourse. The 'underclass' and 'welfare dependency' theses which emerged from the work of American social theorists such as Charles Murray and Lawrence Mead clearly impacted upon the international policy debate in the 1980s, partly due to the legitimisation that they received from the support of the Reagan and Thatcher administrations for their central claims (see e.g. Mead, 1986: Murray, 1984).

Murray's vision of an underclass choosing to avoid work because of the overgenerous nature of welfare benefits had limited direct impact in most European countries (where the author's obsessions with race and 'illegitimacy' were shared by few moderate policy makers). Nevertheless, by the end of the decade, the broader rhetoric of 'the underclass' had become an accepted element within the policy debate in many states (and particularly the UK, where Murray's thesis was much admired in some Conservative circles). Perhaps Mead's arguments about the 'culture of poverty' and the defeatism and passivity of the long-term unemployed were even more influential - indeed, the logical conclusion of Mead's thesis is that workfare policies are required to reintegrate and motivate the unemployed poor.

In Denmark, the impact of the dependency culture thesis was less obvious, and quickly became subordinated to a less well-defined discourse focusing on structural unemployment. The structural unemployment discourse emphasised that unemployment was not determined by the business cycle, but by a mismatch in the supply and demand of qualifications, high and inflexible earnings and the generosity of benefits (Jørgensen \& Lassen, 1993). This broad and rather vague understanding of the unemployment problem 
helped to establish and sustain a widespread consensus around activation, because all stakeholders could agree upon it while still emphasising their own 'version' of the explanation (Torfing, 2003).

However, it should also be noted that the activation discourse retained a strong communitarian element, emphasising the mutual obligations of citizens and the state (Mailand \& Due, 2003), which saw young, middle-class people claiming unemployment benefits being denounced as 'immoral' by some policy makers (Rosdahl \& Weise, 2000; Torfing, 1999). Thus, while the dependency culture thesis in its 'classic', American formulation played a limited role in Denmark, concern over the need to re-establish the social obligations of a 'lost generation' of unemployed young people (Clasen, 2000), and a more general acceptance of the contribution of individuals to labour-market mismatch and therefore structural unemployment, marked a shift in the policy discourse as clear and as important as that seen in the UK.

\section{Cross-national policy diffusion}

In more general terms, there is some evidence that cross-national institutions such as the OECD and the EU also influenced the context for national policy debates. The potential for such organisations to act as a mechanism for cross-national policy diffusion has been noted in a number of instances (Dolowitz \& Marsh, 2000). Certainly, the emphasis of the 1998 European Employment Guidelines on a 'new start' for young people and long-term unemployed is reflected in current policies in both Denmark and the UK. Furthermore, by the mid-1990s the OECD (1994a, 1994b) had begun to strongly advocate more active labour-market policies in order to break the 'dysfunctional division' between the working population and the unemployed. It has been argued that by the end of the decade the OECD (particularly through its 1994 'Jobs Study') had played a crucial role in promoting the language of activation across international boundaries (Sinfield, 2001). Trends towards activation in both countries pre-date the international codification of objectives for ALMPs, and there is some evidence to suggest that Denmark in particular may have informed the EU's strategy, rather than vice versa. However, the EU and OECD can be viewed as providing vital reinforcement for Denmark and the UK (and other states) in their move towards activation.

For many policy analysts, changes in the discourse within international organisations have less explanatory power than theories of direct country-to-country policy diffusion. Mimetic isomorphism remains one of the most common 'political' explanations for the popularity of activation policies in many European states, and centres on the idea that a process of 'learning from abroad' has occurred, with the approach adopted in a lead nation (in this case the United States is most typically cited) being copied by others. There is some evidence of this process in both Denmark and the UK. In Denmark, the terminology adopted during debates on the future of labour-market policy has arguably borrowed from the American language of dependency culture, and the US and British experiences helped to establish compulsory activation as a realistic policy option (Clasen, 2000; Kildal, 2001). However, given the country's historically consistently strong HRD-oriented approach (which in broader training policy pre-dates recent reforms to activation for young people), it is difficult to argue for a process of direct policy transfer in terms of the substantial content of activation strategies. Rather, influence from the Anglo-American world was indirect and mixed with influences from Swedish labour-market policy (Torfing, 1999).

On the other hand, recent moves towards activation in British labour-market policy have frequently been explained as reflecting a process of direct policy transfer from the United States (Deacon, 2000; King, 1995; Mead, 1997). Indeed, the 'learning from America' thesis has become the new orthodoxy informing critical analyses of ALMPs in the UK, which are regularly denounced as being 'like US-style workfare'. There are a number of clear examples of US-UK policy transfer during the 1980s, as the close ideological ties between the Reagan and Thatcher administrations and the influence of the American underclass debate on British Conservative thinking inspired a series of initiatives (Dolowitz, 1997).

However, attempts to link the current government's welfare-to-work strategy to this process of policy transfer tend to be based upon weaker evidence. The strong relationship established between the British Labour Party and American Democrats in the mid-1990s has led some commentators to speculate that the extension of workfare under the Clinton administration inspired recent activation policies for young people in the UK (Dolowitz, Greenwold \& Marsh, 1999; King \& WickhamJones, 1999; Peck \& Theodore, 2001). Yet, as we have noted above, a careful examination of the development of UK policy identifies a limited, but clear, change in direction after 1997. The failure to recognise the Labour government's more HRD-oriented approach (with compulsory activity balanced by choice and clientcentred services) represents a major flaw in the US-UK policy transfer literature. Furthermore, those closer to the policy process have testified that the current government's New Deal reform was also directly influenced by the experiences of Sweden, Denmark and (with regard to the employment subsidy option) Australia (Giddens, 1998; Peck \& Theodore, 2001).

The reality is that there are substantial differences between the application of activation in European states (including Denmark and the UK) and the localised 
workfare practised in the USA (Trickey \& Walker, 2000). There is some evidence that the ideas of American theorists influenced the course of the international debate on labour-market policy during the 1980s (Deacon, 2000), but 'cross-Atlantic diffusion has been a proliferation of ideas about the need to re-balance rights and obligations, more than the application of lessons learnt from US programmes' (Lodemel, 2000: 307).

\section{Discussion and conclusions: different routes, common directions?}

\section{Welfare regimes and activation policies for young people in Denmark and the UK}

The historical traditions and institutional structures of the welfare state will clearly provide the backdrop for the development of all social and labour-market policies. Accordingly, Denmark and the UK, understandably, offered radically different contexts for the development of activation policies for young people during the 1990s. Despite recent moves to curb expenditure, the resilience of Denmark's 'social democratic' welfare state, and specifically its relatively generous social security programmes, in the face of the economic and political challenges of the 1980s and 1990s has been noted (Nordlund, 2000). This stands in contrast to the liberal welfare structures and limited spending commitments that generally continue to characterise British social policy.

We have also noted above the impact of the different countries' welfare systems on the day-to-day experiences of unemployed people. British job seekers are much more likely than their Danish counterparts to experience severe economic hardship. Within activation itself, Danish participants are still relatively more likely to be directed to longer-term training and education opportunities, while the onus in the UK remains on training towards job entry in the immediate to medium term. Other differences in the extent of the integration of services for insured and uninsured claimants, the regulation of benefits and sanctions and the role of the social partners (and particularly the penetration of the private sector in policy delivery) reflect institutional arrangements that are, to a greater or lesser extent, typical of the 'worlds of welfare capitalism' to which these two countries are often assigned. Welfare traditions, or regimes, therefore, continue to provide the context for the process of policy change and weigh heavily on the outcomes experienced by individuals and groups.

However, despite the considerable differences that remain between the Danish and British welfare systems and labour-market policies, the two countries have clearly converged around a relatively similar approach to activation for the young unemployed. The strengthening of compulsory elements within Danish policy has changed the character of a system that has long offered activation as a right, but now demands participation as a responsibility of the young unemployed. In the UK, the neo-liberal stricter benefit regime and training-fare measures introduced by the Conservatives remain in place, but the New Deal clearly represents an attempt to introduce a more holistic approach to dealing with individuals, and a more inclusive system of local policy delivery.

The reasons for this process of policy convergence are far from simple. In the 1980s and 1990s, both countries were required to respond to the social and economic implications of increasing long-term joblessness and the fiscal crisis of the welfare state. That their responses have involved a re-balancing of rights and responsibilities (and so the increased use of compulsion) would appear to be explained by a combination of factors, including: a shift in the international policy discourse, which saw the concepts of welfare dependency and compulsory activation moved to the centre of the political agenda; the diffusion of general ideas from leading liberal welfare states such as the USA; and the early acceptance and promotion of these ideas by parties of the right then in government. However, perhaps most importantly, the combination of strong compulsion and client-centred policies that characterises the Danish and British approaches reflects a coincidence of persistently high youth unemployment at the time of programme development, which required a shift towards client-centred, HRD-oriented approaches, and political change, which allowed strong centre-left governments to progressively re-engineer labour-market policies after centre-right governments had established compulsory activation as an acceptable policy response. (See Levy, 1999, for a discussion of centre-left governments' similarly opportunistic attempts to introduce progressive reforms in conservative/“corporatist' welfare states.)

Welfare regime theories cannot alone provide an adequate explanation for how these two states have arrived at similar (if far from identical) activation policies for young people. Such theories can offer a useful tool for analysing the process of welfare state development that provided the general context for the emergence of new labour-market policies in EU states during the 1990s. Similarly, explanations based upon the transition to a 'Schumpeterian workfare regime' can help us to understand the broad shift towards activation within these labour-market policies. These explanations are of more limited assistance in helping us to understand developments in specific policy areas that appear to run counter to general welfare regime typologies.

For example, attempts to explain the Danish shift towards activation solely with reference to welfare regime theory have focused on the 'active' tradition within Nordic/social democratic labour-market policy (Hvinden et al., 2001), implying that the post-1994 reforms mark a convergence with the mainstream of the 
social democratic welfare regime and its tradition of placing strong work conditions on the unemployed (Clasen et al., 2001). However, it has also been noted that this social democratic mainstream contains widely different approaches to activation, with Denmark's levels of compulsion perhaps standing out amongst the Nordic welfare states, while (for example) Norway's more direct 'labour market attachment' policy focus bears little resemblance to the more holistic 'HRDoriented' Danish model (Lodemel, 2000). Of course, such welfare-regime focused explanations offer little assistance in understanding why the UK - part of an Anglo-Saxon group with 'few if any of the assumed Nordic characteristics in 1997' (Hvinden et al., 2001: 186) - should have moved in a similar direction to Denmark by adding client-centred training policies for young people to its existing, and admittedly typically liberal, stricter benefit regime after 1997.

The reality is that welfare regime typologies, though useful on their own terms, are inherently limited by the need to make generalisations. Yet there is an increasing acceptance that 'hybridness' is in fact a defining feature of welfare states (Arts \& Gelissen, 2002). Furthermore, as Kasza (2002) notes, the cumulative and diverse nature of policy making in the welfare field, the involvement of different sets of policy actors and the influence of foreign models make it increasingly difficult to identify specific policies that demonstrate the internal consistency necessary to validate the welfare regime concept. Activation remains a relatively new area of policy development and analysis. It is therefore important that critical analyses and attempts to explain recent developments focus upon the detail of policy. The above analysis suggests that attempts to explain activation policies with reference to welfare regime theory alone risk neglecting inconvenient, but crucial, features that may indicate a process of policy convergence at odds with expected patterns of development. In more general terms, our analysis adds to existing evidence suggesting that policy-specific comparisons may be rather more helpful in explaining recent trends in activation reform than traditional interpretations based upon the orthodoxies of welfare regime theory (Kasza, 2002). The welfare regime concept is a necessary, but not sufficient, element informing attempts to analyse and compare the development of activation policies for young people and other groups.

\section{The future of activation policies for young people in Denmark and the UK}

In Denmark and the UK, governments will continue to face challenges to their activation strategies. In both countries, concerns have been raised regarding the quality of the supposedly tailored and client-centred programmes directed towards the young unemployed, the limited use of employment subsidies and the real extent of devolved decision-making and partnership all key elements of current activation policies. If economic recession results in significant increases in general unemployment, current policies will come under further pressure, as it becomes apparent that supply-side solutions alone (whatever the strength of their compulsory measures) cannot address the unemployment problem in depressed labour markets. ${ }^{5}$

In the UK, the proposed extension of the New Deal to cover an increasingly large client group could result in the diminution of services for all job seekers, if not matched by additional funding (Hasluck, 2001; Lindsay, 2002). In Denmark, the change of government in 2001, which has returned the centre-right to power, raises new questions about the future direction of labour-market policy. Mooted moves towards an increasingly marketoriented approach, the inclusion of new actors in delivery arrangements, less spending on so-called 'pointless' education and training courses within activation, more emphasis on job search, and a partial amalgamation of 'labour market' and 'social' policy would appear to imply further convergence with the UK, but arguably also a shift towards an explicitly 'labour market attachment' focused-approach. 6

Effective labour-market policies must address the full range of issues affecting the employability of unemployed young people. Activation policies clearly have a role to play, but only as part of a package of measures that also address economic hardship and social exclusion amongst the unemployed and demand deficiency in depressed labour markets. Nevertheless, governments in both Denmark and the UK continue to emphasise supply-side solutions. Meanwhile, recent reforms have demonstrated the fragility of opportunistic attempts to progressively re-engineer activation by linking the apparently contradictory concepts of 'clientcentredness' and 'compulsion'. If both countries are to avoid lurching towards an increasingly workfarist agenda, policy makers must re-state the importance of interventions that are client-centred, offering a choice of provision tailored to the needs of individuals, and which form part of a coherent strategy to promote sustainable employment as well as activating unemployed young people.

5 It should be noted that the more demand-side oriented Danish programme Our Common Concern - the Social Responsibility of Companies was launched by the Ministry of Social Affairs in 1994, during the same period when much of the policy debate on activation was taking place. However, it remains merely a supplement to supply-oriented activation.

6 Some of theses reforms built on plans outlined by the preceding Social Democrat led government, which arguably became increasing sceptical about the value of activation policy in Denmark during the late 1990s. 


\section{Acknowledgements}

The authors are grateful for the helpful comments provided by anonymous referees on an earlier draft of this article.

\section{References}

Abrahamson P (1999). Activation and social policies: comparing France and Scandinavia. In: Bouget D, Palier B, eds Comparing social welfare systems in Nordic Europe and France. Paris, MIRE.

Arts W, Gelissen J (2002). Three worlds of welfare capitalism or more? Journal of European Social Policy 12(2): 137-158.

Clasen J (2000). Motives, means and opportunities: reforming unemployment compensation in the 1990s. West European Politics 23(2): 89-112.

Clasen J, Kvist J, van Oorschot W (2001). On condition of work: increasing work requirements in unemployment compensation schemes. In: Kautto M, Fritzell J, Hvinden B, Kvist J, Uusitalo $\mathrm{H}$, eds. Nordic welfare states in the European context. London, Routledge.

Danish Ministry of Finance (1998). Availability criteria in selected OECD countries. Copenhagen, Ministry of Finance.

Deacon A (1998). Public welfare and private behaviour: the case of welfare to work programmes. Paper presented at the international research conference of the International Social Security Association, Jerusalem, 27 January.

Deacon A (2000). Learning from the US? The influence of American ideas upon 'New Labour' thinking on welfare reform. Policy and Politics 28(1): 5-18.

DfEE (Department for Education and Employment) (1998). The Design of the New Deal for 18-24 year olds. London, DfEE.

Dolowitz D (1997). British employment policy in the 1980s: learning from the American experience. Governance 10(1): $23-42$.

Dolowitz D, Greenwold S, Marsh D (1999). Policy transfer: something old, something new, something borrowed, but why red, white and blue? Parliamentary Affairs 52(4): 719-730.

Dolowitz D, Marsh D (2000). Learning from abroad: the role of policy transfer in contemporary policy making. Governance 13(1): 5-24.

Esping-Andersen G (1990). The Three Worlds of Welfare Capitalism. Cambridge, Polity Press.

Etherington D (1997). Local government and labour market policies in Denmark: is there an alternative to free market policies? Local Government Studies 23(1): 48-58.

Etherington D (1998). From welfare to work in Denmark: an alternative to free market policies? Policy and Politics 26(2): 147-161.

Evans ME (2001). Britain: moving towards a work and opportunity-focused welfare state. International Journal of Social Welfare 10(4): 260-266.

Finn D (2000). Welfare to work: the local dimension. Journal of European Social Policy 10(1): 43-57.

Giddens A (1998). The Third Way: the renewal of social democracy. London, Polity Press.

Grubb D (1999). Making work pay: the role of eligibility criteria for unemployment benefits. Paris, OECD.

Hasluck C (2000) The New Deal for Young People, two years on, Employment Service Research Report ESR41. Sheffield, Employment Service.

Hasluck C (2001). Lessons from the New Deal. New Economy 8(4): $230-234$.

Hvinden B, Heikkila M, Kankare I (2001). Towards activation? The changing relationship between social protection and employment in Europe. In: Kautto M, Fritzell J, Hvinden B, Kvist J, Uusitalo $\mathrm{H}$, eds. Nordic welfare states in the European context. London, Routledge.
ILO (International Labour Organisation) (1998). Employment services and the introduction of youth schemes: the case of the United Kingdom. Geneva, ILO.

Jessop B (1994). The transition to post-Fordism and the Schumpeterian workfare state. In: Burrows R, Loader B, eds. Towards a post-Fordist welfare state? London, Routledge.

Jessop B (1995). Towards a Schumpeterian workfare regime in Britain? Reflections on regulation, governance and the welfare state. Environment and Planning A 27(10): 1613-1626.

Johansson H (2001). Activation policies in Nordic countries: Social Democratic universalism under pressure. Journal of European Area Studies 9(1): 63-77.

Jørgensen H, Lassen M (1993): Indledning [Introduction]. In: Jørgensen H, Lassen M, eds. Efter Zeuthen-rapporten [After the Zeuthen-report]. Aalborg, CARMA.

Jones M (1997). The degradation of labour market programmes Critical Social Policy 17(3): 91-104.

Kasza GJ (2002). The illusion of welfare 'regimes'. Journal of Social Policy 31(2): 271-287.

Kildal N (2001). Workfare tendencies in Scandinavian welfare policies. Geneva, ILO.

King D (1995). Actively seeking work? The politics of unemployment and welfare policy in the United States and Great Britain. Chicago, University of Chicago Press.

King D, Wickham-Jones M (1999). From Clinton to Blair: the Democratic (Party) origins of welfare to work. Political Quarterly 70(1): 62-74.

Larsen F, Abildgaard N, Bredgaard T, Dalsgaard L (2001). Kommunal aktivering - mellem disciplinering og integration [Municipal activation - between social disciplining and social integration]. Aalborg, CARMA.

Larsen F, Stamhus J (2000). Active labour market policy in Denmark: labour market reform, crucial design features and problems of implementation. Aalborg, CARMA.

Levy JD (1999) Vice into virtue? Progressive politics and welfare reform in continental Europe. Politics and Society 27(2): 239-273.

Lindsay C (2002). Long-term unemployment and the employability gap: priorities for renewing Britain's New Deal. Journal of European Industrial Training 26(9): 411-419.

Lodemel I (2000). Discussion: workfare in the welfare state. In: Lodemel I, Trickey H, eds. An offer you can't refuse: workfare in international perspective. Bristol, Policy Press.

Lodemel I, Trickey H (2000). A new contract for social assistance. In: Lodemel I, Trickey H, eds. An offer you can't refuse: workfare in international perspective. Bristol, Policy Press.

Mailand M (1999). Den danske Model lokalt og regionalt konsensus og samarbejde $i$ arbejdsmarkedspolitiske netvork [The Danish Model at local and regional level - consensus and co-operation in labour market policy-networks]. Doctoral dissertation, FAOS, Sociologisk Institut, Københavns Universitet.

Mailand M, Andersen SK (2001). Social Partnerships in Europe - the role of employers and trade unions. A first phase comparative report compiled for The Copenhagen Centre. Copenhagen, The Copenhagen Centre.

Mailand M, Due J (2003). Partsstyringen i arbejdsmarkedspolitikken - perspektiver og alternativer [Steering by social partners in labour market policy - perspectives and alternatives]. In: Pedersen LI, Madsen PK, eds. Drivkrcefter bag arbejdsmarkeds-politikken [Driving forces behind the labour market policy]. Købehavn, Socialforskningsinstitutet.

Martin CJ (forthcoming) Activating employers. Aarhus, Aarhus Universitetsforlag/ Magtudredningen [The Danish Democracy and Power Study].

Martin J (1996). Measures of replacement rates for the purpose of international comparison: a note. OECD Economic Studies 26: 106.

Mead L (1986). Beyond entitlement: the social obligations of citizenship. New York, Free Press. 
Mead L (1997). From welfare to work: lessons from America. London, IEA.

Millar J (2000). Keeping track of welfare reform: the New Deal programmes. York, Joseph Rowntree Foundation.

Murray C (1984). Losing ground: American social policy 1950 1980. New York, Basic Books.

Nord-Larsen M (1997). Ungeindsatsens start [The start of the Special Youth Initiatives]. København, Socialforskningsinstitutet.

Nordlund A (2000). Social policy in harsh times: social security development in Denmark, Finland, Norway and Sweden during the 1980s and 1990s. International Journal of Social Welfare 9(1): 31-42.

OECD (1993). Economic surveys: Denmark. Paris, OECD.

OECD (1994a). The OECD jobs study: evidence and explanations. Paris, OECD.

OECD (1994b). New orientations for social policy. Paris, OECD.

OECD (2000). Employment Outlook, 2000. Paris, OECD.

OECD (2002). Employment Outlook, 2002. Paris, OECD.

Olesen SP (2001). Handlingsplansamtaler - en hån mod de arbejdsløse eller konstruktivt samspil med systemet? [Interviews for individual action plans - scorn towards the unemployed people or fruitful interaction with the authorities?]. Arbejdsliv 3(3): 7-28.

Peck J (1999). New Labourers? Making a New Deal for the workless class. Environment and Planning $C$ : Government and Policy 17(3): 133-161.

Peck J, Jones M (1995). Training and Enterprise Councils: Schumpeterian workfare state or what? Reflections on regulation, governance and the welfare state. Environment and Planning A 27(9): 1361-1396.

Peck J, Theodore N (2001). Exporting workfare/importing welfare to work: Exploring the politics of Third Way policy transfer. Political Geography 20: 427-460.

Riley R, Young G (2001) Does welfare to work policy increase employment? Evidence from the UK New Deal for Young People. London, NIESR.
Rosdahl A, Weise H (2000). When all must be active - workfare in Denmark. In: Lodemel I, Trickey H, eds. An offer you can't refuse: workfare in international perspective. Bristol, Policy Press.

Ross F (2000). Framing welfare reform in affluent societies: rendering restructuring more palatable? Journal of Public Policy 20(2): 169-193.

Salomaki A, Munzi T (1999). Net replacement rates of the unemployed: a comparison of various approaches, Ecofin Economic Paper 133. Brussels, European Commission.

Schultz T (2001). Retten til forsørgelse - en grundlovssikret rettighed? Om grundlovens $\S 75$, stk. 2 [The right to social benefits - a right according to the constitution? About the constitution $\S 75,2]$. Arbejdsliv 3(1).

Sinfield A (2001). Benefits and research in the labour market. European Journal of Social Security 3(3): 209-235.

Standing G (2000). Unemployment and income security. Geneva, ILO.

Torfing J (1999). Workfare with welfare: recent reforms of the Danish welfare state. Journal of European Social Policy 9(1): $5-28$.

Torfing J (2003). Den stille revolution i velfærdsstaten: fra forsørgelse og hierarki til aktivering og netværksstyring [The silent revolution of the welfare state - from social benefits towards activation and network steering]. In: Pedersen LI, Madsen PK, eds. Drivkrafter bag arbejdsmarkeds-politikken [Driving forces behind the labour market policy]. Købehavn, Socialforskningsinstitutet.

Trickey H, Walker R (2000). Steps to compulsion within British labour market policies. In: Lodemel I, Trickey H, eds. An offer you can't refuse: workfare in international perspective. Bristol, Policy Press.

Wells B (2001). From Re-start to the New Deal: a recent history of labour market intervention, paper presented at the Institute for Labour Research Conference, Leicester, 2-4 July, at $\underline{\text { http://www.essex.ac.uk/ilr/ }}$ 